\title{
Evaluation of sagittal balance and spinopelvic parameters in patients with lumbar disc herniation
}

\section{Lomber disk hernili olgularda omurgada sagital denge ve spinopelvik parametrelerin değerlendirilmesi}

\author{
Esin BARAN ${ }^{1}$, Mustafa KARADEMIIR ${ }^{2}$
}

Sivas Numune State Hospital, Department of Physical Medicine and Rehabilitation, Siva

Sivas Cumhuriyet University School of Medicine, Department of Neurosurgery, Sivas

Corresponding author: Mustafa Karademir, Sivas Cumhuriyet University School of Medicine, Department of Neurosurgery, Sivas

E-mail:krdmr58@gmail.com

Received/Accepted: December 25,2018/December 27,2018

Conflict of interest: There is not a conflict of interest.

\begin{abstract}
SUMMARY
Objective: The objective of this study was to analyze sagittal balance throughout with spinopelvic parameters, in patients with a lumbar disc herniation and evaluate these patients with functional quality assessment questionnaires.

Method: A total of 88 adult patients were evaluated in this study. All these patients were examined clinically in a physical medicine and rehabilitation policlinic, from one physician in Sivas Numune State Hospital for a lumbar disc herniation between 01 March-01 November 2018. The physical examination findings and records in the patient's files were evaluated. The Oswestry Disability Questionnaire (ODQ), Roland Morris Questionnaire (RDQ) and Health Assessment Questionnaire (HAQ) were evaluated for all voluntary patients. All patients were confirmed with full spinal anteroposterior and lateral radiographs and lumbar MRI. Three group pathologies were evaluated in this study: Group1; disc herniation with bulging, Group 2; one level disc herniation and Group 3 multilevel disc herniation, including lumbar disc protrusion, extrusion, and sequestration. Spino-pelvic parameters; lumbar lordosis (LL), pelvic incidence (PI), pelvic tilt (PT) and sacral slope (SS) were measured on full spine radiographs in a standing position.

Results: LL was significantly less by multilevel disc herniation group as compared with bulging group and one level disc herniation group $(\mathrm{p}<0.05)$. It was a poor correlation between LL and waist circumference by multilevel disc herniation group. When compared groups with functional assessment questionnaires, all groups were not statistically different each from other. We demonstrated not significantly different by all three groups between ODI, HAQ and RDI scores.

Conclusions: The spinal sagittal imbalance caused by LDH is one type of compensatory response to prevent low back pain. This mechanism mainly includes a loss of LL and PT. Two important factors that need to be considered are the paravertebral muscles strengthening to prevent sagittal imbalance and keeping the body weight and waist circumference in the normal range.
\end{abstract}

Keywords: Sagittal balance, Spinopelvic parameters, Oswestry Disability Index, Roland Morris Index, Health Assessment Questionnaire

ÖZET

Amaç: Bu çalışmada amaç lomber disk hernili olgularda, omurgada sagittal dengenin spinopelvik parametreler ve fonksiyonel yaşam kalitesi anketleri eşliğinde dğerlendirilmesidir.

Yöntem: Çalışmaya 88 olgu dahil edilmiştir.Tüm olguların fizik muayene ve yaşam kalitesi anketleri 01 Mart- 01 Kasım 2018 tarihleri arasında Sivas Numune Hastanesi Fiziksel Tip ve Rehabilitasyon polikliniğinde tek uzman doktor tarafından yapılmıştır. Olguların fizik muayene bulguları ve hasta dosyalarındaki değerlendirmeye alınmıştır. Her olgu için Oswestry Disabilite İndeksi, Roland Morris ve Sağlık Yaşam Kalitesi Anketleri değerlendirilmiştir. Tüm olguların spinal direkt AP-lateral röntgenogramları ve lomber MR görüntüleri değerlendirmeye alınmıştır. Olgular 3 gruba ayrılmıştır. Grup1 bulging grubu olgular, Grup2 tek seviye disk hernisi olan olgular, Grup3 çok seviye disk hernisi olan olgular olarak sınıflandırılmıştır. Spinopelvik parametreler; lomber lordoz (LL), Pelvik İnsidens (PI), Sakral eğim (SE) 
ve Pelvik eğim (PE) açıları ayakta durur pozisyonda çekilen spinal röntgenogramlar üzerinde değerlendirmeye alınmıștır.

Bulgular: LL çok seviyeli disk hernisi olan grupta, bulging grubu ve tek seviyeli disk hernisi grubu olgulara göre istatistiki açıdan anlamlı olarak düşük bulunmuştur $(\mathrm{p}<0.05)$. Çok seviye disk hernisi grubunda LL ile bel çevresi arasında negatif yönlü bir korelasyon izlenmiştir. Gruplar fonksiyonel yaşam kalitesi anketleri açısından karşılaştırıldığında aralarında anlamlı bir fark bulunmamıştır.

Sonuç: Lomber disk hernili olgularda spinal sagittal dengesizlik, bel ağrısını azaltmaya yönelik olarak vücudun bir savunma mekanizması olarak ortaya çıkmaktadır. Bu mekanizma genellikle LLve PE azalması yönünde gelişmektedir. Sagittal dengesizliğin oluşmasını engellemek için iki önemli faktör ortaya çıkmaktadır; vücut ağırlı̆ı̆ının ve bel çevresinin normal sınırlar arasında tutulması gerektiği kanaatindeyiz.

Anahtar sözcükler: Sagital denge, spinopelvic parametreler, Oswestry Disabilite İndeksi, Roland Morris İndeksi, Sağlık Yaşam Kalitesi Anketi

\section{INTRODUCTION}

Herniation of the nucleus pulposus (HNP) occurs when the gel-like substance nucleus pulposus breaks through the annulus fibrosis. The rate of symptomatic lumbar disc herniation (LDH) is $1 \%$ to $3 \%$ of the general population. $\mathrm{LDH}$ may cause back pain, lower limb radiation pain or sensory disturbance, cauda equina, and radiculopathy ${ }^{1}$.

Sagittal balance is a situation where the individual is able to maintain a stable standing position with minimal muscle effort. Sagittal balance is the result of the interaction of bone morphology (mainly pelvic and vertebral morphology), disc and ligaments mechanical behavior, muscle strength and resistance, and ability to introduce compensating mechanisms ${ }^{2}$. When one of the factors disrupted, a sagittal imbalance occurs. Numerous studies focus on the radiologic parameters to evaluate the state of sagittal spinal imbalance, but it's blank of the clinical symptoms 3.

LDH is a common disease, mainly causing low back pain and radiculopathy. But in some patients, the complaint is unable to stand erect, stooping with walking difficulty as well as inability to lift heavy objects in front. The clinical symptom is similar to sagittal spinal imbalance. Studies have shown that lumbar disc herniation, degenerative lumbar instability, and other degenerative lumbar spinal diseases, such as hyperplasia of articular processes, wedging of vertebral bodies, and hyper-osteogeny, are often secondary to disc degeneration. Intervertebral disc degeneration is related to many factors, including spine biomechanics, biology, injury, inflammation, and nutrition. By studying the intervertebral disc, researchers have clarified the pathological changes involved in intervertebral disc degeneration but have ignored the roles of biomechanical factors during its development. When a person is maintaining a standing position, various parts of the body must be in coordination, forming different spine sagittal patterns and resulting in different biomechanical characteristics. Previous studies have indicated that there are changes in the spinal-pelvic sagittal force lines in patients with spinal deformities and lumbar degenerative diseases to varying degrees ${ }^{4}$.

The objective of this study was to analyze sagittal balance throughout with spinopelvic parameters, in a population of 88 patients with a lumbar disc herniation and evaluate these patients with functional quality assessment questionnaires.

\section{MATERIAL AND METHODS}

This retrospective study is approved from the local ethical committee, and all voluntary patients have signed the informed consent form before the beginning of the study. A total of 88 adult patients were evaluated in this study. The average age of the subjects was $43.81 \pm 13.06(20-65)$ years; there were 78 males and 10 females. Anthropometric characteristics of patients are summarised in Table 1. 
Table 1: Anthropometric characteristics of patients

\begin{tabular}{|c|c|c|c|c|}
\hline \multirow[b]{2}{*}{ Variable } & \multicolumn{3}{|c|}{ Groups } & \multirow[b]{2}{*}{$p$} \\
\hline & $\begin{array}{c}\text { Bulging } \\
(n=10)\end{array}$ & $\begin{array}{c}\text { One level disc } \\
\text { herniation } \\
(n=34)\end{array}$ & $\begin{array}{c}\text { Multilevel disc } \\
\text { herniation } \\
(n=44)\end{array}$ & \\
\hline Age & $38.80 \pm 15.66$ & $45.29 \pm 12.47$ & $47.36 \pm 11.07$ & 0.138 \\
\hline BMI (kg/m²) & $27.42 \pm 6.79$ & $28.70 \pm 5.67$ & $29.37 \pm 4.59$ & 0.560 \\
\hline Waist circumference (cm) & $88.30 \pm 19.26$ & $96.35 \pm 14.23$ & $98.09 \pm 9.25$ & 0.095 \\
\hline \multicolumn{4}{|l|}{ Gender } & \multirow{3}{*}{0.081} \\
\hline Woman & $10(100.0)$ & $22(64.7)$ & $32(72.7)$ & \\
\hline Man & $0(0.0)$ & $12(35.3)$ & $12(27.3)$ & \\
\hline
\end{tabular}

All these patients were examined clinically in a physical medicine and rehabilitation policlinic, from one physician in Sivas Numune State Hospital for a lumbar disc herniation between 01 March-01 November 2018. The physical examination findings and records in the patient's file were evaluated. The Oswestry disability questionnaire, Roland Morris questionnaire and Health Assessment Questionnaire were evaluated for all voluntary patients. All patients were confirmed with full spinal anteroposterior and lateral radiographs and lumbar MRI ${ }^{5-7}$.

Patients were excluded from the study if they had one or more of the following criteria :

- Background of any spinal surgery (included simple lumbar discectomy)

- Spinal disease (trauma or tumor)

- Scoliosis

- Coxo-femoral pathology

- Isthmic lysis with or without spondylolisthesis.

Three group pathologies were evaluated in this study: Group1; disc herniation with bulging, Group 2; one level disc herniation and Group 3 multilevel disc herniation, including lumbar disc protrusion, extrusion, and sequestration. Spinopelvic parameters were measured on full spine radiographs in a standing position. The patient was asked to stand in a standardized erect posture with the hands placed on supports and the knees held in extension. The edges of the radiographic film were squared with respect to the horizontal and vertical axes. All radiological parameters were measured by a single author.

Pelvic parameters included in this analysis were the pelvic incidence, the sacral slope, and the pelvic tilt. The pelvic incidence (PI) was defined as the angle between the perpendicular to the sacral plate and the line connecting the midpoint of the sacral plate to the bi-coxo-femoral axis. The $\mathrm{PI}$ is a morphological parameter, considered as a constant, independent of the spatial orientation of the pelvis. The sacral slope (SS) corresponds to the angle between the sacral plate and the horizontal plane. The SS is a positional parameter, varying according to the pelvis positioning. The pelvic tilt (PT) corresponds to the angle between the line connecting the midpoint of the sacral plate to the bi-coxo-femoral axis and the vertical plane. As said for the SS, the PT is also a positional parameter. The PI represents the algebraic sum of the SS and the PT: PI = SS + PT thus if we consider the incidence of one subject when the sacral slope increases the pelvic tilt decreases and vice versa. The LL was defined as the extension spinal segment above the sacral plate. It was measured using Cobb's method from the sacral plate to the upper endplate of the most inclined vertebrae into the thoracolumbar junction zone (Figure 1) ${ }^{4}$. 


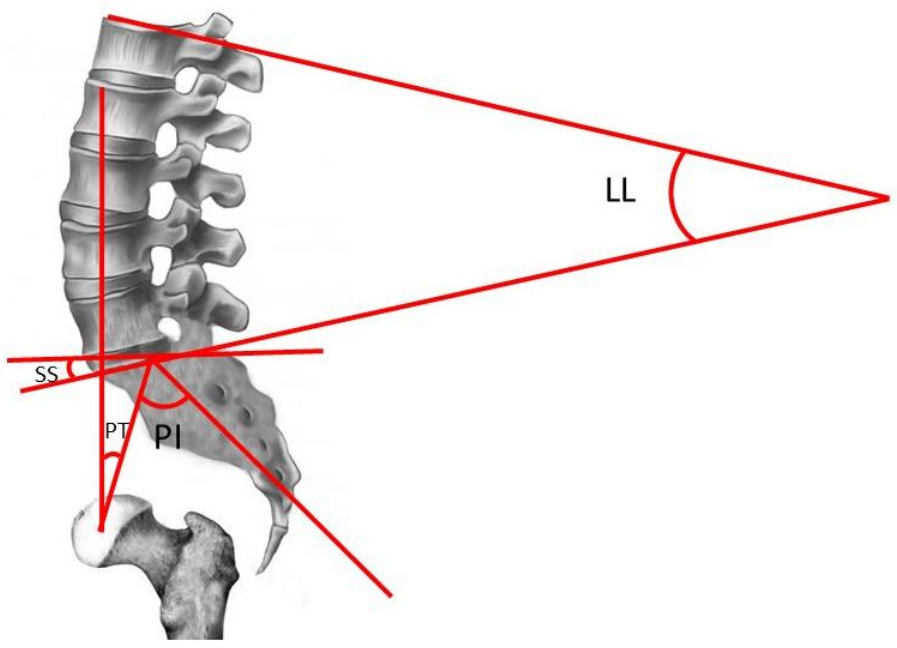

Figure 1: Spinopelvic parameters

\section{Statistical Analysis}

Histogram and q-q plots were examined, ShapiroWilk's test was applied to assess the data normality. Levene's test was used to assess the variance homogeneity. To compare the differences between groups; independent samples $t$-test, Mann-Whitney $\mathrm{U}$ test, one-way analysis of variance (ANOVA) and Kruskal-Wallis tests were used for continuous variables. Pearson chi-square analysis was used for categorical variables. Tukey, Siegel-Castellan, and Bonferroni adjusted $z$ posthoc tests were performed for multiple comparisons. Correlation analysis was performed by Spearman test. Analyses were conducted using TURCOSA (www.turcosa.com.tr, Turcosa Analytics Ltd Co, Turkey) statistical software. A $p$ value less than $5 \%$ was considered as statistically significant.

\section{RESULTS}

LL was demonstrated about 45 degrees by the bulging group and one level disc herniation group. By multilevel disc herniation group, we demonstrated LL as 40 degrees. LL was significantly less by multilevel disc herniation group as compared with bulging group and one level disc herniation group $(\mathrm{p}<0.05)$. Similarly, PT was demonstrated by bulging group 20degrees, by one level disc herniation group 19 degrees and by multilevel disc herniation group 10 degrees. By multilevel disc herniation group, PT was significantly less than one level disc herniation group and bulging group $(\mathrm{p}<0.05)$ (Table 2).

Table 2: Spinopelvic parameters

\begin{tabular}{|l|c|c|c|c|}
\hline \multirow{2}{*}{ Variable } & \multicolumn{3}{|c|}{ Groups } & \multirow{2}{*}{} \\
\cline { 2 - 4 } & $\begin{array}{c}\text { Bulging } \\
(\boldsymbol{n = 1 0 )}\end{array}$ & $\begin{array}{c}\text { One level disc } \\
\text { herniation } \\
(\boldsymbol{n = 3 4 )}\end{array}$ & $\begin{array}{c}\text { Multilevel disc } \\
\text { herniation } \\
(\boldsymbol{n = 4 4 )}\end{array}$ & \multirow{p}{*}{} \\
\hline LL & $45.0(45.0-60.0)^{\mathbf{a}}$ & $45.0(40.0-60.0)^{\mathbf{a}}$ & $40.0(30.0-45.0)^{\mathbf{b}}$ & 0.005 \\
\hline PI & $50.5(25.0-60.0)$ & $55.5(45.0-68.0)$ & $50.0(45.0-59.5)$ & 0.249 \\
\hline SS & $46.0(42.0-51.0)$ & $40.0(33.0-46.0)$ & $41.0(35.0-45.0)$ & 0.175 \\
\hline PT & $20.0(10.0-20.0)^{\mathbf{a}}$ & $19.0(11.0-30.0)^{\mathbf{a}}$ & $10.0(7.5-20.0)^{\mathbf{b}}$ & 0.022 \\
\hline
\end{tabular}

We demonstrated a poor correlation between LL and waist circumference by multilevel disc herniation group $(r h o=-0.387 ; p<0.05)$ (Table $3)$. 
Table 3: Correlation with age, Body mass index (BMI) and waist circumference

\begin{tabular}{|l|c|c|c|}
\hline Groups & AGE & BMI & $\begin{array}{c}\text { Waist } \\
\text { Circumference }\end{array}$ \\
\hline Bulging (n=10) & & & \\
\hline LL & -0.472 & -0.025 & -0.038 \\
\hline PI & 0.695 & 0.491 & 0.564 \\
\hline SS & 0.593 & 0.438 & 0.553 \\
\hline PT & -0.243 & -0.082 & -0.100 \\
\hline One level disc herniation $(\boldsymbol{n = 3 4 )}$ & & & -0.155 \\
\hline LL & -0.178 & -0.237 & 0.166 \\
\hline PI & -0.005 & 0.188 & 0.022 \\
\hline SE & 0.006 & 0.046 & 0.126 \\
\hline PE & -0.059 & 0.186 & \\
\hline Multilevel disc herniation $(\boldsymbol{n}=\mathbf{4 4})$ & & & $-\mathbf{0 . 3 8 7 ^ { * }}$ \\
\hline LL & -0.090 & -0.136 & -0.122 \\
\hline Pi & -0.295 & -0.121 & -0.276 \\
\hline SE & -0.054 & -0.295 & -0.093 \\
\hline PE & -0.098 & 0.130 & \\
\hline
\end{tabular}

We compared groups with functional assessment questionnaires; all groups were not statistically different each from other. We demonstrated not significantly different by all three groups between
Oswestry disability score (ODI), Health Assesment (HAQ) and Roland Morris questionnaire (RDI) scores ( $>0,05)$ (Table 4).

Table 4: Functional assessment scores

\begin{tabular}{|c|c|c|c|c|}
\hline & \multicolumn{3}{|c|}{ Gruplar } & \multirow[b]{2}{*}{$p$} \\
\hline & $\begin{array}{c}\text { Bulging } \\
(n=10)\end{array}$ & $\begin{array}{c}\text { One level disc } \\
\text { herniation } \\
(n=34)\end{array}$ & $\begin{array}{l}\text { Multilevel disc } \\
\text { herniation } \\
(n=44)\end{array}$ & \\
\hline RDİ & $13.0(9.0-14.0)$ & $15.0(13.0-18.0)$ & $16.0(12.0-19.0)$ & 0.091 \\
\hline HAQ & $8.5(5.0-12.0)$ & $9.0(5.0-17.0)$ & $10.0(5.0-14.5)$ & 0.628 \\
\hline ODİ & $46.0(30.0-51.0)$ & $40.0(32.0-54.0)$ & $37.0(26.0-53.5)$ & 0.685 \\
\hline
\end{tabular}

We compared the relation between spinopelvic parameters and functional assessment scores. Also, we demonstrated no a statistically significant correlation between spinopelvic parameters and functional assessment scores (p>0,05) (Table 5). 
Table 5: Correlation between spinopelvic parameters and functional assessment scores

\begin{tabular}{|c|c|c|c|c|}
\hline Groups & $\mathbf{L L}$ & PI & SS & PT \\
\hline \multicolumn{5}{|c|}{ Bulging $(n=10)$} \\
\hline RDİ & -0.231 & 0.439 & 0.456 & -0.487 \\
\hline HAQ & -0.120 & 0.332 & 0.354 & -0.525 \\
\hline ODİ & 0.142 & -0.134 & 0.378 & -0.167 \\
\hline \multicolumn{5}{|c|}{ One level herniation $(n=34)$} \\
\hline RDİ & -0.124 & 0.129 & 0.242 & 0.203 \\
\hline HAQ & -0.164 & 0.069 & 0.088 & 0.157 \\
\hline ODI & -0.007 & 0.321 & 0.139 & 0.256 \\
\hline \multicolumn{5}{|c|}{ Multilevel herniation $(n=44)$} \\
\hline RDI & -0.199 & -0.149 & -0.068 & -0.045 \\
\hline HAQ & -0.014 & -0.037 & -0.099 & -0.021 \\
\hline ODİ & -0.085 & 0.005 & -0.215 & 0.149 \\
\hline
\end{tabular}

\section{DISCUSSION}

The development of lumbar disc herniation may be associated with certain alterations in the sagittal balance of the spine. The relationships between the gravity line of the body and some spinal parameters have often been examined, and attention is being directed toward the importance of spinopelvic balance. Rajni's et al. demonstrated that when the spinopelvic para- meters were examined in cases with lumbar disc herniation; it is observed that the SS angle is small, the sacrum is more vertical, and the lumbar lordosis is decreased compared to the normal population. These results are associated with higher pressure on the intervertebral discs and also progressive degeneration of the discs and correlate with disc herniation. Anteriorly displacement of the gravity line may be cause spino-pelvic instability, sagittal imbalance and thereafter occurs posterior paravertebral muscle contraction and low back pain ${ }^{8}$.

In this study, we examined the spatial relationship of the spine and the pelvis in patients with lumbar disc herniation. We used three different groups to compare sagittal spinal balance with differently lumber discs herniation types (Bulging, protrusion, extrusion, sequestration) and one or multilevel disc herniation models. We demonstrated that LL was significantly less by multilevel disc herniation group as compared with bulging group and one level disc herniation group. Previous studies have suggested that specific changes in alignment and the characteristics of the lumbar lordosis are responsible for degenerative changes and symptomatic back pain ${ }^{9}$. Evcik and
Yucel reported that patients who had chronic low back pain were statistically more likely to have a vertically oriented sacrum and less lumbar lordosis than age- and sex-matched controls who had acute back pain. An iatrogenic loss of lumbar lordosis accompanied by an anterior shift of the sagittal vertical axis creates a constellation of symptoms and problems with sagittal spinal balance that is difficult to treat ${ }^{10}$. In our study, we think that by multilevel disc herniation group may be more posterior paravertebral muscle contraction and low back pain and accordingly less lumbar lordosis.

The orientation of pelvis is defined by two positional parameters: the PT and the SS. Barrey et al. demonstrated in their study that the PT was significantly increased for patients with disc herniation. In our study, we evaluated that PT was significantly high compared to normal population. Moreover, we detected that PT is significantly great by bulging group compared to other groups. We believe that this result may be related to acute paravertebral muscle spasm. Paravertebral muscle spasm causes severe low back pain by an initial form of lumbar disc herniation, so the disc is bulging. Endo et al. suggested that biomechanically, the loss of lordosis would result in the anterior displacement of the $\mathrm{C} 7$ plumb line as well as a more vertical pelvic tilt increase to compensate for the anterior translation of the gravitational axis. The correlations among parameters found in our study concord with that conclusion ${ }^{11}$.

In this study, we demonstrated a poor correlation between LL and waist circumference by 
multilevel disc herniation group. Higher waist circumference is related to obesity and sagittal imbalance. This result is accordingly witted Wang et al.; the sagittal spinopelvic parameters and obesity valuables reach statistically significant differences between adolescents with LDH and normal adolescents, adolescents with LDH had lower PI, SS, and LL ${ }^{12}$.

When compared groups with functional assessment questionnaires, all groups were not statistically different each from other. We demonstrated not significantly different by all three groups between Oswestry disability score (ODI), Health Assesment (HAQ) and Roland Morris questionnaire(RDI) scores. Also, Oh et al. suggested that lumbar disc herniation is related with decreased functional assessment scores, but in our study, we detected that the results of this questionnaire are not relevant with the types of lumbar disc herniation ${ }^{13}$. These scores are independent of types and levels of disc herniations.

In our study, we found a deterioration in spinopelvic parameters in the patient group with single-level disc herniation according to the bulging group. As disc degeneration progressed, we found that the deterioration in spinopelvic parameters in our patient group with multilevel herniation progressed further and became statistically significant. However, there is no relation between the spinopelvic parameters determined by the progression of the disc degeneration and the clinical reflection of these pathologies in our patients. In this case, we determined that functional disorders affecting the pain or daily life defined by the patients are not related to the degree of the disease. We believe that this may be due to the subjective and complex structure of the pain.

\section{CONCLUSION}

The sagittal spinal imbalance caused by LDH is one type of compensatory response to prevent low back pain. Compensatory mechanism of spine sagittal imbalance mainly includes a loss of lumbar lordosis and pelvic tilt. Trunk muscle plays an important role in maintaining the sagittal spinal balance. Two important factors that need to be considered are the paravertebral muscles strengthening to prevent sagittal imbalance due to lumbar disc herniation and keeping the body weight, and waist circumference in the normal range is essential.

\section{REFERENCES}

1. Wang $\mathrm{T}$, Wang $\mathrm{H}$, Zhang $\mathrm{D}$, Zhang $\mathrm{Y}$,
Ding W. Radiological analysis for thoracolumbar disc herniation in spinopelvic sagittal alignment. :2-7.

2. Lamartina $C$, Berjano $P$, Petruzzi $M$, Sinigaglia A, Casero G, Cecchinato R, et al. Criteria to restore the sagittal balance in deformity and degenerative spondylolisthesis. European Spine Journal. 2012;21(SUPPL. 1):27-31.

3. Liang C, Sun J, Cui X, Jiang Z, Zhang W, Li T. Spinal sagittal imbalance in patients with lumbar disc herniation: Its spinopelvic characteristics, strength changes of the spinal musculature and natural history after lumbar discectomy. BMC Musculoskeletal Disorders [Internet]. 2016;17(1):1-8. Available from: http://dx.doi.org/10.1186/s12891-0161164-y

4. Wei X, Gengwu L, Chao C, Yifan L, Shang $\mathrm{S}$, Ruixi $\mathrm{H}$, et al. Correlations between the sagittal plane parameters of the spine and pelvis and lumbar disc degeneration. Journal of Orthopaedic Surgery and Research. 2018;13(1):1-9.

5. Stevens ML, Lin CCW, Maher CG. The Roland Morris Disability Questionnaire. Journal of Physiotherapy. 2016;62(2):116.

6. Mehra A, Baker D, Disney S, Pynsent PB. Oswestry disability index scoring made easy. Annals of the Royal College of Surgeons of England. 2008;90(6):497-9.

7. Bruce B, Fries JF. Bruce(haq).pdf. 2003;6:1-6.

8. Illes T. The importance of spinopelvic parameters in patients with lumbar disc lesions. 2002;104-8.

9. Roussouly P, Gollogly S, Berthonnaud E, Dimnet J. Classification of the Normal Variation in the Sagittal Alignment of the Human Lumbar Spine and Pelvis in the Standing Position Pierre Roussouly, MD ,* Sohrab Gollogly , MD ,* Eric Berthonnaud , Ph.D. $\dagger$ and. 2005;30(3):2005.

10. Evcik D, Yücel A. Lumbar lordosis in acute and chronic low back pain patients. Rheumatology International. 2003;23(4): 163-5.

11. Endo K, Suzuki H, Tanaka H, Kang Y, Yamamoto K. Sagittal spinal alignment in patients with lumbar disc herniation. 
European Spine Journal. 2010;19(3):4358.

12. Wang T, Wang H, Liu FY, Yang DL, Ma L, Ding WY. The characteristics of spinopelvic sagittal parameters and obesity factors for adolescents with lumbar disc herniation. International Journal of Clinical and Experimental Medicine. 2016;9(7):14321-8.
13. Oh B-H, Kim H-H, Kim C-Y, Nam C-W. Comparison of physical function according to the lumbar movement method of stabilizing a patient with chronic low back pain. Journal of Physical Therapy Science [Internet]. 2015;27(12):3655-8. Available from:

https://www.jstage.jst.go.jp/article/jpts/27/ 12/27_jpts-2015-603/_article 